\title{
Changes in FGF21 Serum Concentrations and Liver mRNA Expression in an Experimental Model of Complete Lipodystrophy and Insulin-Resistant Diabetes
}

\author{
A. ŠPOLCOVÁ ${ }^{1 *}$, M. HOLUBOVÁ ${ }^{1 *}$, B. MIKULÁŠKOVÁ ${ }^{1}$, V. NAGELOVÁ ${ }^{1}$, \\ A. ŠTOFKOVÁ ${ }^{2}$, Z. LACINOVÁ ${ }^{3}$, J. JURČOVIČOVÁ ${ }^{2}$, M. HALUZÍK ${ }^{3}$, L. MALETÍNSKÁ ${ }^{1}$, \\ B. ŽELEZNÁ ${ }^{1}$ \\ *These authors contributed equally.
}

${ }^{1}$ Institute of Organic Chemistry and Biochemistry, Academy of Sciences of the Czech Republic, Prague, Czech Republic, ${ }^{2}$ Department of Normal, Pathological and Clinical Physiology, Third Faculty of Medicine, Charles University, Prague, Czech Republic, ${ }^{3}$ Third Department of Medicine, First Faculty of Medicine, Charles University, Prague, Czech Republic

Received December 6, 2013

Accepted March 21, 2014

On-line June 5, 2014

\section{Summary}

Patients with obesity and type 2 diabetes often display high levels of the anti-diabetic factor fibroblast growth factor-21 (FGF21), suggesting that the overproduction of FGF21 may result from increased adiposity in an attempt by white adipose tissue (WAT) to counteract insulin resistance. However, the production of FGF21 diabetes in the absence of WAT has not been examined. In this study, we investigated the effects of lipodystrophy in A-ZIP F-1 mice on FGF21 production in relation to diabetes. A-ZIP F-1 mice displayed high FGF21 plasma levels resulting from enhanced FGF21 mRNA expression in the liver. Concomitant enhancement of FGF21 receptor (FGFR1) and glucose transporter 1 (GLUT-1) mRNA expression was observed in the muscles of A-ZIP F-1 mice. Furthermore, the activation of hypothalamic NPY and AgRP mRNA expression positively correlated with plasma levels of FGF21 but not active ghrelin. Our study demonstrates that an increased FGF21 plasma level in lipodystrophic A-ZIP F-1 mice results mainly from up-regulated liver production but does not suffice to overcome the lipodystrophy-induced severe type 2-diabetes and insulin resistance in the liver linked to the augmented liver fat deposition.

\section{Key words}

FGF21 • A-ZIP mice • Lipodystrophy • Insulin resistance • Fatty liver • GLUT-1

\section{Corresponding author}

B. Železná, Institute of Organic Chemistry and Biochemistry, Flemingovo nám. 2, 16610 Prague 6, Czech Republic. E-mail: zelezna@uochb.cas.cz

\section{Introduction}

White adipose tissue (WAT) contributes significantly to the regulation of energy homeostasis through the production of numerous factors that act in both endocrine and autocrine/paracrine manners. In addition, numerous hormones and cytokines that play a role in regulating energy homeostasis also influence its behavior. One substance that markedly affects adipose tissue metabolism is a recently discovered adipokine with anti-diabetic properties: fibroblast growth factor-21 (FGF21). FGF21 is predominantly produced in the liver and exerts its actions primarily on WAT (Yang et al. 2012a) where both components necessary for its complete action, the FGF21 receptor (FGFR1) and the co-receptor $\beta$ Klotho (Kurosu et al. 2007), are expressed. In WAT, FGF21 promotes glucose uptake through enhancing the expression of the insulin independent glucose transporter GLUT-1 (Kharitonenkov et al. 2005), thereby decreasing adipocyte lipolysis and hepatic lipogenesis (Yang et al. 2012a). Moreover, FGF21 can also induce hypothalamic 
NPY expression (Ishida et al. 2009), as its non-saturable, unidirectional influx across the blood brain barrier has been demonstrated (Hsuchou et al. 2007).

Previous studies have shown that FGF21 levels and its production in the liver are markedly increased in both rodent and human models of obesity and insulin resistance (Kharitonenkov et al. 2005). However, significant resistance to FGF21 has been demonstrated in mice with diet-induced obesity (Fisher et al. 2010).

Based on the fact that FGF21 predominantly targets adipose tissue, we hypothesized that FGF21 effects on glucose homeostasis are modulated in the absence of adipose tissue. To evaluate the importance of adipose tissue to the anti-diabetic actions of FGF21, we utilized A-ZIP F-1 lipodystrophic mice expressing a dominant/negative A-ZIP/F protein under the control of an adipose tissue specific aP2 enhancer/promoter. These mice almost completely lack WAT and display reduced amounts of inactive brown adipose tissue (BAT) (Moitra et al. 1998). The lack of white adipose tissue in the A-ZIP F-1 mice results in markedly enhanced ectopic lipid storage in muscles and the liver resulting in severe insulin resistance in these organs (Kim et al. 2000), similarly as in type-2 diabetes (Moitra et al. 1998, Kim et al. 2000). A-ZIP F-1 mice suffer from marked hyperphagia due to a complete leptin deficiency (Moitra et al. 1998).

In this study, we aimed to characterize circulating levels and mRNA expressions of anti-diabetic hormone FGF21 and its receptor FGFR1 in A-ZIP F-1 mice and their healthy littermates and to correlate possible differences with diabetic lipodystrophic phenotype. We also addressed whether possible abnormalities in FGF21 levels might contribute to the modulation of hypothalamic neuropeptides in A-ZIP mice.

\section{Methods}

\section{Animals}

All experiments followed the ethical guidelines for animal experiments, the Czech Republic law No. 246/1992 and were approved by the Committee for experiments with laboratory animals at the Academy of Sciences of the Czech Republic.

All A-ZIP F1 mice (National Institute of Health, Bethesda, Maryland, USA) hemizygous for the transgene, along with wild-type littermates, were on the FVB/N background. Female A-ZIP F1 $(n=12)$ and FVB/N $(n=13)$ mice aged 8-10 months were maintained on a $12-\mathrm{h}$ light/dark cycle (light period began at 6:00 a.m.) at $23{ }^{\circ} \mathrm{C}$ with free access to water and a standard rodent pellet diet (Rod 18-A, LASvendi, Soest, Germany).

Mice were sacrificed by decapitation in the morning after $2 \mathrm{~h}$ without an access to food. Trunk blood was collected, and plasma was prepared and stored at $-20{ }^{\circ} \mathrm{C}$. The brown adipose tissue (BAT), musculus gastrocnemius, liver, spleen, and pancreas were dissected from each mouse, weighed, and then snap frozen in liquid nitrogen and stored at $-70^{\circ} \mathrm{C}$. Brains were dissected and then placed in isopentane at -15 to $-20{ }^{\circ} \mathrm{C}$ for one $\min$. Then, samples were frozen on dry ice and stored at $-70{ }^{\circ} \mathrm{C}$ until sectioning.

\section{Blood plasma components}

The levels of blood glucose and ketone bodies were measured using a Glucocard glucometer (Arkray, Kyoto, Japan). Plasma insulin and active ghrelin concentrations were quantified by RIAs (Millipore, St. Charles, MI, USA), while leptin and FGF21 concentrations were determined by ELISAs (Millipore, St. Charles, MI, USA and BioVendor, Brno, Czech Republic, respectively). Triglyceride levels were measured using an enzymatic photometric assay (Lachema, Brno, Czech Republic). All measurements were carried out according to the manufacturers' protocols.

Determination of $m R N A$ expression in the muscle, liver and $B A T$

Samples of liver and muscle were homogenized using a MagNA Lyser Instrument and MagNA Lyser Green Beads (Roche Diagnostics GmbH, Mannheim, Germany). Total RNA was extracted from the homogenized samples using a MagNA Pure instrument and a MagNA Pure Compact RNA Isolation (Tissue) kit (Roche Diagnostics GmbH, Mannheim, Germany) similarly as previously (Maletínská et al. 2011). The RNA concentrations were determined by measuring the absorbance at $260 \mathrm{~nm}$ (BioPhotometer, Eppendorf AG, Hamburg, Germany). The RNA samples were reverse transcribed into cDNA using the High-Capacity cDNA Reverse Transcription Kit (Applied Biosystems, Foster City, CA, USA). The mRNA expressions of genes of interest (UCP-1 in the brown adipose tissue, GLUT1, GLUT4, FGF21, FGFR1, and Klotho in the muscle; FGFR1 and Klotho in the pancreas, FGF21, PPAR $\alpha$, FGFR1, and Klotho in the liver) were determined using an ABI PRISM 7500 instrument (Applied Biosystems, 
Foster City, CA, USA). PCR reactions included TaqMan $^{\circledR}$ Universal PCR Master Mix, NO AmpErase ${ }^{\circledR}$ UNG, specific TaqMan $^{\circledR}$ Gene Expression Assays (Applied Biosystems, Foster City, CA, USA) and nuclease-free water (Fermentas Life Science, Vilnius, Lithuania). PCR reactions were performed at least in duplicate in a total reaction volume of $25 \mu \mathrm{l}$. The PCR reactions were performed according to standard conditions $\left(50{ }^{\circ} \mathrm{C}\right.$ for $2 \mathrm{~min}, 95^{\circ} \mathrm{C}$ for $10 \mathrm{~min}$, followed by 40 cycles of $95{ }^{\circ} \mathrm{C}$ for $15 \mathrm{~s}$ and $60^{\circ} \mathrm{C}$ for $\left.1 \mathrm{~min}\right)$. The expression of $\beta_{2}$ microglobulin (B2M) was used to compensate for variations in RNA input and the efficiency of reverse transcription. The modified formula $2^{-\Delta \mathrm{Ct}}$ was used for calculating relative gene expression.

Determination of $m R N A$ expression in the medial basal hypothalamus

A cryostat was used to cut $200 \mu \mathrm{m}$ coronal sections (starting $-1.25 \mathrm{~mm}$ from the bregma) that were mounted on glass slides and immersed in absolute ethyl alcohol for $50 \mathrm{~s}$. Immediately thereafter, an area including the median eminence, arcuate nuclei, ventromedial nuclei, and dorsomedial nuclei was dissected from serial sections under microscopy using a razor blade, similarly as previously (Holubová et al. 2013). The tissue was homogenized in RNA extraction lysis buffer, and stored at $-70{ }^{\circ} \mathrm{C}$ until RNA extraction was performed.

Total RNA from the medial basal hypothalamus was isolated using an RNAqueous Micro Kit (Ambion, Austin, TX). The concentration of RNA was determined by measuring the absorbance at $260 \mathrm{~nm}$ using a NanoDrop 2000 Spectrophotometer (Thermo Fisher Scientific, Waltham, MA). The RNA samples were reverse transcribed into cDNA using a High Capacity cDNA Reverse Transcription Kit (Applied Biosystems, Foster City, CA). The quantitative PCR reactions were performed using TaqMan Assays (Applied Biosystems, Foster City, CA). A fluorogenic probe for the control
GAPDH gene was labeled with the VIC reporter dye. Probes for the target genes NPY, AgRP, CART, PRLH and POMC were labeled with the FAM reporter dye. Each reaction contained the TaqMan Universal Master Mix (Applied Biosystems, Foster City, CA). Samples were run in triplicate. The thermal cycling was performed according to manufacturer's protocol: 40 cycles at $95{ }^{\circ} \mathrm{C}$ for $15 \mathrm{~s}$ and $60^{\circ} \mathrm{C}$ for $1 \mathrm{~min}$ with an initial setup step of $10 \mathrm{~min}$ at $95{ }^{\circ} \mathrm{C}$. The data were collected using a CFX96 Real time system (Bio-Rad, Hercules, CA). RNA inputs were calculated using a multiple comparative method for the mRNAs of interest and GAPDH. Statistical analyses were performed using Genex Ver. 5 software (MultiD Analyses AB, Goteborg, Sweden).

\section{Statistics}

The data are presented as the mean \pm SEM for the number of animals indicated in the Figures and Tables. They were analyzed by a t-test using GraphPad Software (San Diego, CA, USA).

\section{Results}

Although the body mass of A-ZIP F-1 mice did not differ from the FVN/N controls, organomegaly in A-ZIP F-1 was demonstrated by a higher mass of the liver, pancreas, and spleen compared to FVN/N controls (Table 1). The increased liver mass in A-ZIP F-1 mice included a substantial fat deposition. BAT mass (Table 1) and the expression of uncoupling protein-1 (UCP-1) mRNA (Fig. 1) was significantly attenuated. The complete absence of WAT, the main source of leptin, resulted in negligible leptin levels (Table 2). Glucose and insulin levels in the A-ZIP F-1 mice were increased by several fold compared to controls (Table 2), suggesting a pronounced insulin resistance. The A-ZIP F-1 mice also displayed enhanced triglyceride levels and significantly lower levels of ketone bodies (Table 2).

Table 1. Weight of organs of controls and A-ZIP mice.

\begin{tabular}{lcccc}
\hline Mice & BAT $[\mathbf{g}]$ & Liver $[\mathbf{g}]$ & Spleen $[\mathbf{g}]$ & Pancreas [g] \\
\hline $\begin{array}{l}\text { Control } \\
\text { A-ZIP }\end{array}$ & $0.14 \pm 0.02$ & $1.57 \pm 0.11$ & $0.14 \pm 0.01$ & $0.19 \pm 0.02$ \\
\hline
\end{tabular}

Data are mean $\pm \mathrm{SEM}, \mathrm{n}=11-12$ animals per group. Significance is $* \mathrm{P}<0.05, * * \mathrm{P}<0.01$ and $* * * \mathrm{P}<0.001$ using Student's t-test. 
Table 2. Metabolic parameters of controls and A-ZIP mice.

\begin{tabular}{lllllll}
\hline Mice & $\begin{array}{l}\text { Glucose } \\
{[\mathbf{m m o l} / \mathbf{l}]}\end{array}$ & $\begin{array}{l}\text { Insulin } \\
{[\mathbf{n g} / \mathbf{m l}]}\end{array}$ & $\begin{array}{l}\text { Leptin } \\
{[\mathbf{n g} / \mathbf{m l}]}\end{array}$ & $\begin{array}{l}\text { Triglycerides } \\
{[\mathbf{m g} / \mathbf{d l}]}\end{array}$ & $\begin{array}{l}\text { Ketone } \\
\text { bodies } \\
{[\mathbf{m m o l} / \mathbf{l}]}\end{array}$ & $\begin{array}{l}\text { Ghrelin } \\
{[\mathbf{n g} / \mathbf{m l}]}\end{array}$ \\
\hline Control & $6.54 \pm 0.84$ & $4.59 \pm 1.66$ & $14.35 \pm 3.07$ & $186.68 \pm 34.03$ & $0.40 \pm 0.11$ & $0.085 \pm 0.006$ \\
$A-Z I P$ & $32.49 \pm 3.44$ & $\begin{array}{l}1189.72 \pm 227.24 \\
* * *\end{array}$ & $\begin{array}{l}0.23 \pm 0.02 \\
* * *\end{array}$ & $\begin{array}{l}1119.02 \pm 213.00 \\
* * *\end{array}$ & $0.23 \pm 0.02$ & $0.088 \pm 0.007$ \\
& $* * *$ & & & & & \\
\hline
\end{tabular}

Data are mean $\pm \mathrm{SEM}, \mathrm{n}=8-12$ animals per group. Significance is $* * * \mathrm{P}<0.001$ using Student's t-test.

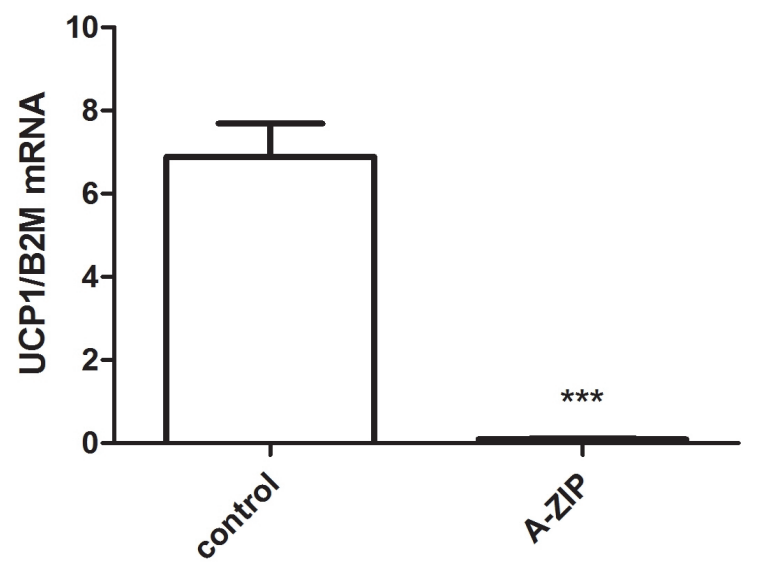

Fig. 1. Expression of UCP1 in brown adipose tissue. Data are mean \pm SEM, $n=11-12$ animals per group. The data were normalized to $\beta_{2}$-microglobulin and analyzed by the unpaired t-test. Significance is $* * \mathrm{P}<0.01$ using Student's t-test.
The levels of active ghrelin were similar in A-ZIP F-1 and control mice (Table 2) while the expression of the orexigenic neuropeptides NPY and AgRP were significantly enhanced in the medial basal hypothalamus of A-ZIP F-1 mice compared to the controls (Fig. 2a,b). In contrast, the expressions of CART, PRLH, and POMC did not differ significantly in the medial basal hypothalamus of A-ZIP F-1 mice compared to controls (Fig. 2c,d,e).

The high plasma FGF21 levels observed in A-ZIP F-1 mice (Fig. 3) obviously resulted from its enhanced expression in the liver, the main source of FGF21 (Fig. 4a). FGF21 expression in the muscles of A-ZIP F-1 mice was not altered compared to controls (Fig. 4c). In the BAT of A-ZIP F-1 mice, FGF21 expression was even lower compared to other organs (Fig. 4b).
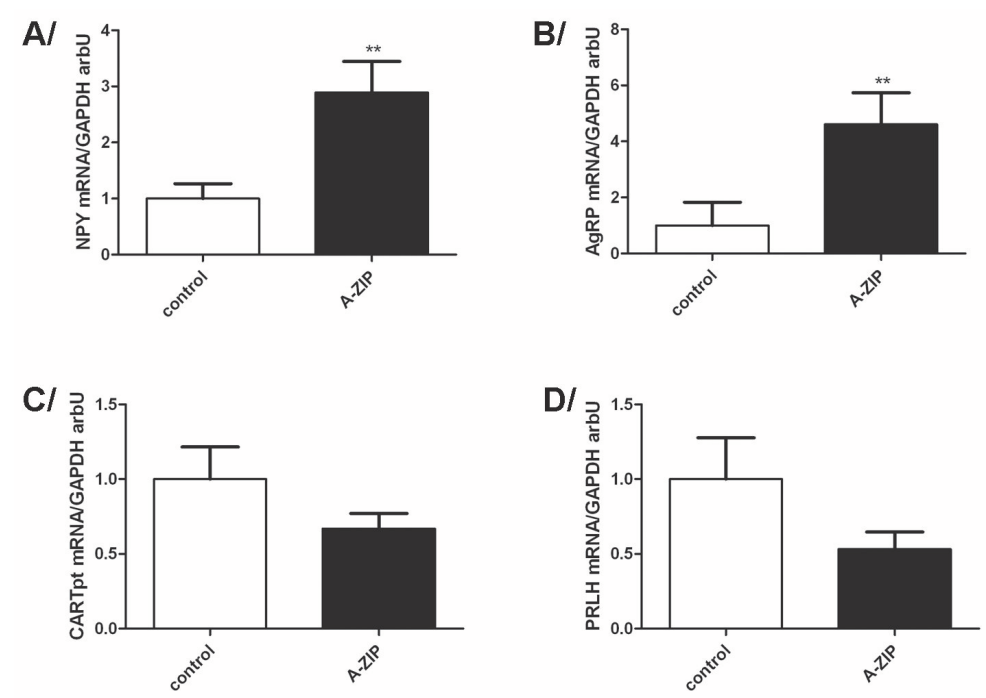

Fig. 2. Expression of different neuropeptides in medial basal hypothalamus. A/ NPY, B/ AgRP, C/ CART, peptide D/ PRLH, E/ POMC. The data were normalized to GAPDH and analyzed by the unpaired t-test. Data are mean \pm SEM, $n=11-12$ animals per group. Significance is $* * \quad \mathrm{P}<0.01$ using Student's t-test.

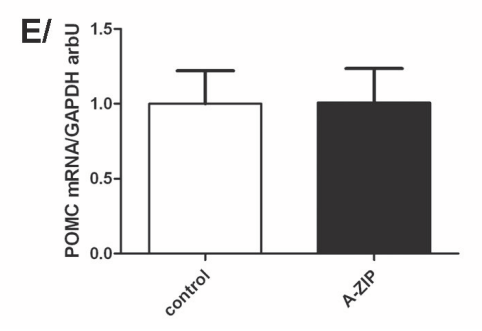




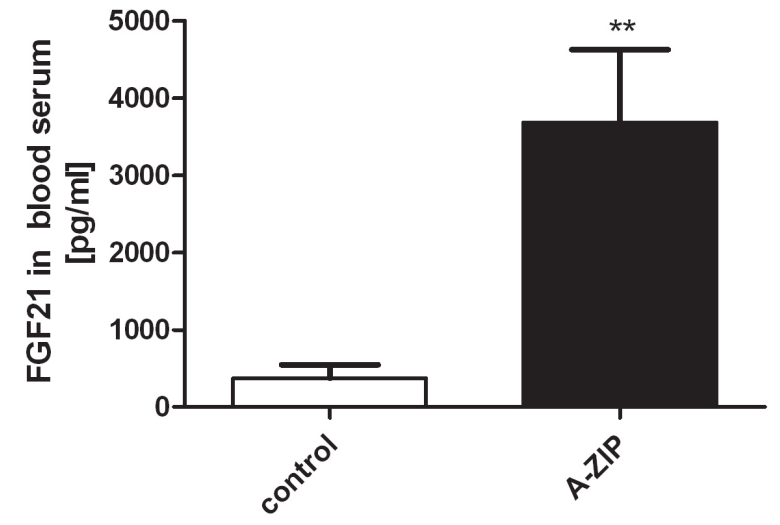

Fig. 3. FGF2 1 in blood serum. Data are mean $\pm S E M, n=11-12$ animals per group. Significance is $* * \quad \mathrm{P}<0.01$ using Student's t-test.
Differences in the expression of PPAR $\alpha$ (peroxisome proliferator-activated receptor $\alpha$ ), the main regulator of FGF21 production (Inagaki et al. 2007), were not evident in the livers of A-ZIP F-1 mice compared to controls (Fig. 4d).

Klotho mRNA expressions in the liver, pancreas and muscle did not differ between A-ZIP F-1 and controls and so did not FGFR1 mRNA expressions in the liver. FGFR 1 mRNA expressions in the pancreas were lower in A-ZIP F-1 than in controls (not shown).

In the muscle of A-ZIP F-1 mice, FGFR1 mRNA expression was higher in A-ZIP F-1 than in controls (Fig. 5c). Besides, an increased mRNA expression of GLUT-1 mRNA (Fig. 5a) but not insulin sensitive GLUT-4 (Fig. 5b) was detected in the muscle.
A/

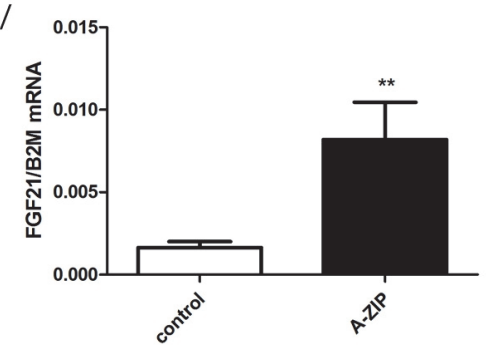

Cl

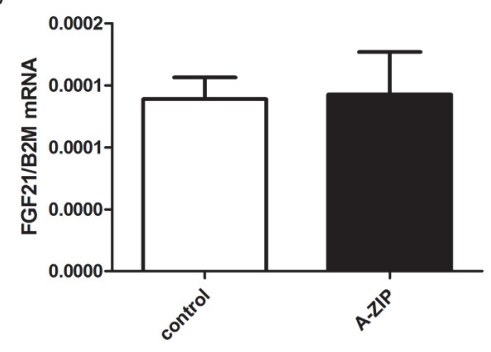

Al

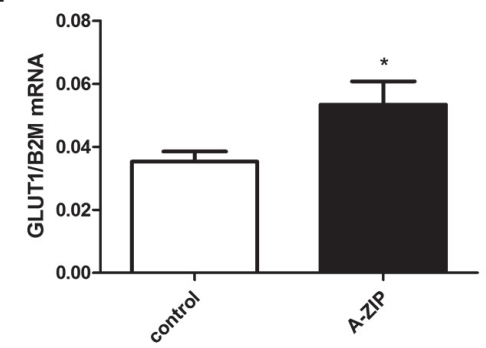

CI

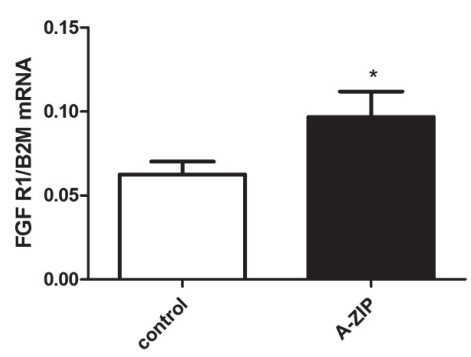

B/

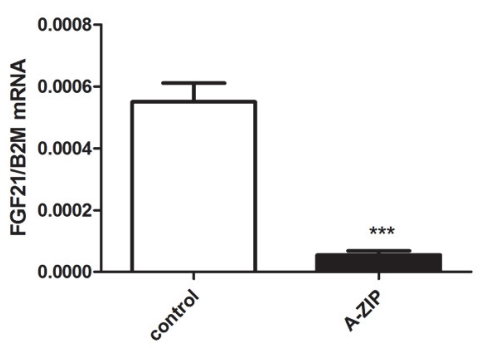

D/

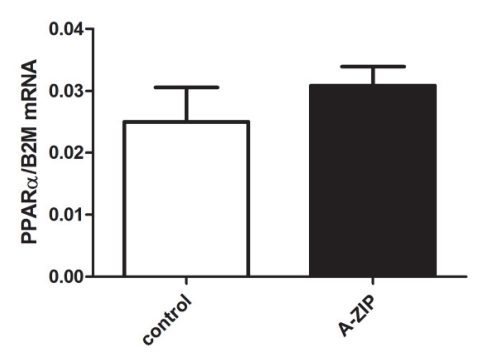

$\mathrm{B} /$

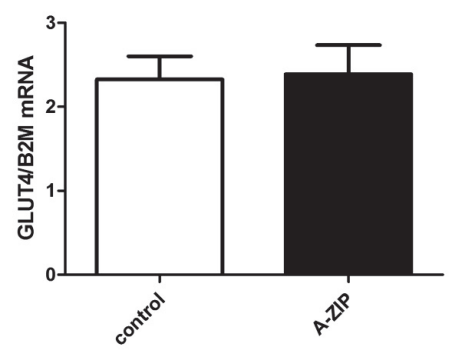

D/

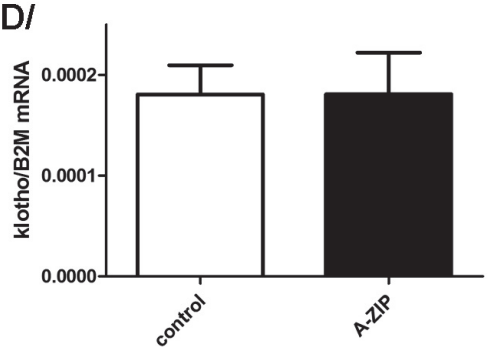

Fig. 4. FGF21 expression in different organs and PPARa expression in liver. A/ FGF21 in liver, B/ FGF21 in BAT, C/ FGF21 in muscle, D/ PPARa in liver. The data were normalized to $\beta_{2}$-microglobulin and analyzed by the unpaired t-test. Data are mean \pm SEM, $\mathrm{n}=11-12$ animals per group. Significance is $* * \mathrm{P}<0.01, * * * \quad \mathrm{P}<0.001$ using Student's t-test.

Fig. 5. Parameters related to FGF21. A/ GLUT1 in muscle, B/ GLUT4 in muscle, C/ FGF21 R1 in muscle, D/ Klotho in muscle. The data were normalized to $\beta_{2}$-microglobulin and analyzed by the unpaired t-test. Data are mean \pm SEM, $n=11-12$ animals per group. Significance is $* \quad \mathrm{P}<0.05$ using Student's t-test. 


\section{Discussion}

The most important finding of this study is that diabetic lipodystrofic A-ZIP mice have markedly increased serum concentration and liver mRNA expression of the insulin-sensitizing factor FGF21. Similarly, serum FGF21 levels generally correlated with FGF21 expression in hepatocytes (Yang et al. 2012b). FGF21 levels in lipodystrophic HIV infected patients showed a strong positive correlation with indicators of lipodystrophy, insulin resistance, and liver injury (Domingo et al. 2010). Moreover, FGF21 was found to correlate positively with non-alcoholic fatty liver disease (NAFLD) (Dushay et al. 2010) and has been recently marked as a hepatokine induced to the liver by metabolic stress such as hepatitis, fatty degeneration, cirrhosis and liver tumors (Yang et al. 2013). We suggest that in A-ZIP F-1, an extreme fat deposition, linked to liver insulin resistance found previously by Kim et al. (2000), could represent metabolic stress to the liver that could induce FGF21 production. Lindegaard et al. (2013) found that not increased levels of FGF21 but its muscle mRNA expression correlated with systemic insulin resistance in lipodystrophic HIV infected patients. Nevertheless, A-ZIP mice in this study had similar muscle mRNA expression of FGF21 as nondiabetic controls despite the fact that insulin resistance in skeletal muscles was previously demonstrated in A-ZIP F-1 mice by Kim et al. (2000).

Activating FGF21 in the liver of A-ZIP F-1 mice was probably not accomplished through an enhanced PPAR $\alpha$ mRNA expression that did not differ from controls but rather by an enhanced level of free fatty acids that was demonstrated previously in A-ZIP F-1 mice (Moitra et al. 1998, Haluzík et al. 2002). Besides, in severely hyperglycemic A-ZIP F-1 mice, glucose activated transcription factor ChREB could stimulate FGF21 similarly as in isolated hepatocytes overexpressing dominant active ChREBP (Iizuka et al. 2009).

FGF21 could function in the liver A-ZIP F-1 by an autocrine/paracrine effect, because both FGFR1 and $\beta$ Klotho are expressed in the liver (Ito et al. 2000) and FGF21 production in the liver is many times higher than in other organs such as muscle and BAT (Yang et al. 2013).

Via FGFR1, FGF21 anti-diabetic action is accomplished normally mainly in the white adipose tissue by inhibiting adipocyte lipolysis that impacts the liver by attenuating lipogenesis, steatosis, and hepatic stress (Yang et al. 2012b). Recently, adiponectin was found obligatory for the glucose-lowering and insulin-sensitizing effects of
FGF21 (Holland et al. 2013, Lin et al. 2013) and adiponectin inhibitory effect on liver production of proinflammatory cytokines was reported (Lin et al. 2013). The lack of the adipose tissue as the essential source of adiponectin was probably the reason why FGF21 glucoselowering and insulin-sensitizing effects mediated normally by adiponectin did not prove in A-ZIP F-1 mice.

In the skeletal muscle of A-ZIP F-1 mice compared to controls, enhanced mRNA expressions of FGFR1 and insulin independent glucose transporter GLUT-1 were detected. As GLUT-1 mRNA expression in myocytes in vitro was shown to be increased by FGF21 (Mashili et al. 2011), we hypothesize that increased levels of FGF21 in A-ZIP F-1 might up-regulate GLUT-1 in the skeletal muscle. Interestingly, in lipodystrophic mice overexpressing SREB P1c, pharmacological doses of FGF21 did not affect GLUT-1 expression in residual WAT (Véniant et al. 2012).

Organomegaly in the A-ZIP F-1 mice is thought to be at least in part due to extremely high insulin levels that potentially cross-react with and activate the IGF1 receptor, thereby stimulating parenchymal organ growth. Here, we show that the levels of the growth hormone secretagogue ghrelin do not significantly differ between A-ZIP mice and controls and therefore do not contribute to the organomegaly observed in A-ZIP F-1 mice via stimulating the GH/IGF1 axis. Thermogenesis in A-ZIP F-1 is probably attenuated due to a decreased UCP-1 mRNA expression and lower BAT mass in A-ZIP.

The augmented expressions of NPY and AgRP mRNAs and expressions of anorexigenic POMC, CART and PRLH mRNAs similar to controls in the medial basal hypothalamus of A-ZIP F-1 mice in our study indicate a hyper-activation of the central orexigenic/anabolic pathways which is in agreement with hyperphagia of A-ZIP F-1 (Moitra et al. 1998). However, the levels of active ghrelin, the direct stimulator of NPY/AgRP orexigenic pathway (Nakazato et al. 2001), were not enhanced in A-ZIP F-1 mice compared to controls. Based on the finding that FGF21 enhanced hypothalamic NPY mRNA expression (Ishida et al. 2009), we might consider a marked increase in FGF-21 levels - besides the absence of leptin - as a factor that could contribute to an increased hypothalamic NPY mRNA expression in A-ZIP mice.

\section{Conclusions}

In sum, our study demonstrates that both liver mRNA expression and serum level of anti-diabetic factor 
FGF21 are markedly up-regulated in lipodystrophic A-ZIP F-1 mice. However, the increase in FGF21 does not suffice to overcome lipodystrophy-induced severe type-2 diabetes. Increased FGF21 concentrations may contribute to the activation of the orexigenic/anabolic NPY/AgRP pathway in the medial basal hypothalamus.

\section{Conflict of Interest}

There is no conflict of interest.

\section{Acknowledgements}

This research was supported by the Grant Agency of the Czech Republic (grant numbers 303/10/1368 and P303/12/0576) and the Grant Agency of the Academy of Sciences of the Czech Republic (RVO:61388963). The authors would like to thank Dr. A. Kiss and Dr. Z. Pirník (Institute of Experimental Endocrinology, SAS, Slovakia) for their kind support with the isolation of the medial basal hypothalamus and $\mathrm{H}$. Vysušilová for excellent technical assistance.

\section{References}

DOMINGO P, GALLEGO-ESCUREDO JM, DOMINGO JC, GUTIÉRREZ MDEL M, MATEO MG, FERNÁNDEZ I, VIDAL F, GIRALT M, VILLARROYA F: Serum FGF21 levels are elevated in association with lipodystrophy, insulin resistance and biomarkers of liver injury in HIV-1-infected patients. AIDS 24: 26292637, 2010.

DUSHAY J, CHUI PC, GOPALAKRISHNAN GS, VARELA-REY M, CRAWLEY M, FISHER FM, BADMAN MK, MARTINEZ-CHANTAR ML, MARATOS-FLIER E: Increased fibroblast growth factor 21 in obesity and nonalcoholic fatty liver disease. Gastroenterology 139: 456-463, 2010.

FISHER FM, CHUI PC, ANTONELLIS PJ, BINA HA, KHARITONENKOV A, FLIER JS, MARATOS-FLIER E: Obesity is a fibroblast growth factor 21 (FGF21)-resistant state. Diabetes 59: 2781-2789, 2010.

HALUZÍK M, DIETZ KR, KIM JK, MARCUS-SAMUELS B, SHULMAN GI, GAVRILOVA O, REITMAN ML: Adrenalectomy improves diabetes in A-ZIP/F-1 lipoatrophic mice by increasing both liver and muscle insulin sensitivity. Diabetes 51: 2113-2118, 2002.

HOLLAND WL, ADAMS AC, BROZINICK JT, BUI HH, MIYAUCHI Y, KUSMINSKI CM, BAUER SM, WADE M, SINGHAL E, CHENG CC, VOLK K, KUO MS, GORDILLO R, KHARITONENKOV A, SCHERER PE: An FGF21-adiponectin-ceramide axis controls energy expenditure and insulin action in mice. Cell Metab 17: 790-797, 2013.

HOLUBOVÁ M, ŠPOLCOVÁ A, DEMIANOVÁ Z, SÝKORA D, FEHRENTZ JA, MARTINEZ J, STOFKOVA A, JURČOVIČOVÁ J, DRÁPALOVÁ J, LACINOVÁ Z, HALUZÍK M, ŽELEZNÁ B, MALETÍNSKÁ L: Ghrelin agonist JMV 1843 increases food intake, body weight and expression of orexigenic neuropeptides in mice. Physiol Res 62: 435-444, 2013.

HSUCHOU H, PAN W, KASTIN AJ: The fasting polypeptide FGF21 can enter brain from blood. Peptides 28: 23822386, 2007.

IIZUKA K, TAKEDA J, HORIKAWA Y: Glucose induces FGF21 mRNA expression through ChREBP activation in rat hepatocytes. FEBS Lett 583: 2882-2886, 2009.

INAGAKI T, DUTCHAK P, ZHAO G, DING X, GAUTRON L, PARAMESWARA V, LI Y, GOETZ R, MOHAMMADI M, ESSER V, ELMQUIST JK, GERARD RD, BURGESS SC, HAMMER RE, MANGELSDORF DJ, KLIEWER SA: Endocrine regulation of the fasting response by PPARalpha-mediated induction of fibroblast growth factor 21. Cell Metab 5: 415-425, 2007.

ISHIDA Y, SAKAHARA S, TSUTSUI C, KAIYA H, SAKATA I, ODA S, SAKAI T: Identification of ghrelin in the house musk shrew (Suncus murinus): cDNA cloning, peptide purification and tissue distribution. Peptides 30: 982-990, 2009.

ITO S, KINOSHITA S, SHIRAISHI N, NAKAGAWA S, SEKINE S, FUJIMORI T, NABESHIMA YI: Molecular cloning and expression analyses of mouse betaklotho, which encodes a novel Klotho family protein. Mech Dev 98: $115-119,2000$. 
KHARITONENKOV A, SHIYANOVA TL, KOESTER A, FORD AM, MICANOVIC R, GALBREATH EJ, SANDUSKY GE, HAMMOND LJ, MOYERS JS, OWENS RA, GROMADA J, BROZINICK JT, HAWKINS ED, WROBLEWSKI VJ, LI DS, MEHRBOD F, JASKUNAS SR, SHANAFELT AB: FGF-21 as a novel metabolic regulator. J Clin Invest 115: 1627-1635, 2005.

KIM JK, GAVRILOVA O, CHEN Y, REITMAN ML, SHULMAN GI: Mechanism of insulin resistance in A-ZIP/F-1 fatless mice. J Biol Chem 275: 8456-8460, 2000.

KUROSU H, CHOI M, OGAWA Y, DICKSON AS, GOETZ R, ELISEENKOVA AV, MOHAMMADI M, ROSENBLATT KP, KLIEWER SA, KURO-O M: Tissue-specific expression of betaKlotho and fibroblast growth factor (FGF) receptor isoforms determines metabolic activity of FGF19 and FGF2. J Biol Chem 282: 26687-26695, 2007.

LIN Z, TIAN H, LAM KS, LIN S, HOO RC, KONISHI M, ITOH N, WANG Y, BORNSTEIN SR, XU A, LI X: Adiponectin mediates the metabolic effects of FGF21 on glucose homeostasis and insulin sensitivity in mice. Cell Metab 17: 779-789, 2013.

LINDEGAARD B, HVID T, GRØNDAHL T, FROSIG C, GERSTOFT J, HOJMAN P, PEDERSEN BK: Expression of fibroblast growth factor-21 in muscle is associated with lipodystrophy, insulin resistance and lipid disturbances in patients with HIV. PLoS One 8: e55632, 2013.

MALETÍNSKÁ L, MATYŠKOVÁ R, MAIXNEROVÁ J, SÝKORA D, PÝCHOVÁ M, ŠPOLCOVÁ A, BLECHOVÁ M, DRÁPALOVÁ J, LACINOVÁ Z, HALUZÍK M, ŽELEZNÁ B: The Peptidic GHS-R antagonist [DLys(3)]GHRP-6 markedly improves adiposity and related metabolic abnormalities in a mouse model of postmenopausal obesity. Mol Cell Endocrinol 343: 55-62, 2011.

MASHILI FL, AUSTIN RL, DESHMUKH AS, FRITZ T, CAIDAHL K, BERGDAHL K, ZIERATH JR, CHIBALIN AV, MOLLER DE, KHARITONENKOV A, KROOK A: Direct effects of FGF21 on glucose uptake in human skeletal muscle: implications for type 2 diabetes and obesity. Diabetes Metab Res Rev 27: 286-297, 2011.

MOITRA J, MASON MM, OLIVE M, KRYLOV D, GAVRILOVA O, MARCUS-SAMUELS B, FEIGENBAUM L, LEE E, AOYAMA T, ECKHAUS M, REITMAN ML, VINSON C: Life without white fat: a transgenic mouse. Genes Dev 12: 3168-3181, 1998.

NAKAZATO M, MURAKAMI N, DATE Y, KOJIMA M, MATSUO H, KANGAWA K, MATSUKURA S: A role for ghrelin in the central regulation of feeding. Nature 409: 194-198, 2001.

VÉNIANT MM, HALE C, HELMERING J, CHEN MM, STANISLAUS S, BUSBY J, VONDERFECHT S, XU J, LLOYD DJ: FGF21 promotes metabolic homeostasis via white adipose and leptin in mice. PLoS One 7: e40164, 2012.

YANG C, JIN C, LI X, WANG F, MCKEEHAN WL, LUO Y: Differential specificity of endocrine FGF19 and FGF21 to FGFR1 and FGFR4 in complex with KLB. PLoS One 7: e33870, 2012a.

YANG C, WANG C, YE M, JIN C, HE W, WANG F, MCKEEHAN WL, LUO Y: Control of lipid metabolism by adipocyte FGFR1-mediated adipohepatic communication during hepatic stress. Nutr Metab (Lond) 9: 94, 2012 b.

YANG C, LU W, LIN T, YOU P, YE M, HUANG Y, JIANG X, WANG C, WANG F, LEE MH, YEUNG SC, JOHNSON RL, WEI C, TSAI RY, FRAZIER ML, MCKEEHAN WL, LUO Y: Activation of liver FGF21 in hepatocarcinogenesis and during hepatic stress. BMC Gastroenterol 13: 67, 2013. 